\title{
The Effect of Social Interaction to the Tendency of Food Innovativeness: Evidence from West Java
}

\author{
$1^{\text {st }}$ Ujang Maman ${ }^{1}, 2^{\text {nd }}$ Edmon Daris ${ }^{1}, 3^{\text {rd }}$ Iwan Aminuddin ${ }^{1}, 4^{\text {th }}$ Akhmad Riyadi Wastra ${ }^{1}, 5^{\text {th }}$ \\ E.Oos M. Anwas ${ }^{2}$ \\ \{ujang.maman@uinjkt.ac.id $\left.{ }^{1}\right\}$
}

\author{
Agribusiness Post Graduate Program, UIN Syarif Hidayatullah Jakarta ${ }^{1}$, Center of Curriculum and \\ Books, Ministry of Education and Culture, Indonesia ${ }^{2}$
}

\begin{abstract}
The strong dependence upon rice staple food and decreasing of paddy land areas in Indonesia will cause the country to face the staple food scarcity. The model of extension to change the eating pattern is inevitable. For such purpose, the research explored social interaction - mutual understanding, partnership, family relationship and communication - between cassava consumers with surrounding community, the effect of social interaction to the food innovativeness. Based on Slovin formula with 5\% of error probability and adopting the stratified random sampling technique, the research sample is 182 people. Data collecting was conducted during May-July 2018 by close questionnaire in Likert scale. The multiple regression analysis indicated the strongly significant effect of communication and family relationship as well as the significant effect of partnership to the tendency of food innovativeness.
\end{abstract}

Keywords: Social interaction, food innovativeness, and cassava eater's surrounding community, Indonesia

\section{Introduction}

The existence the custom community in Cirendeu village, district of Cimahi, Bandung, West Java should deeply be considered. Following the ancestor, they have seriously prohibited to consume the paddy-rice. Their daily staple food is cassava-rice which its variety based on the cassava raw material. They are small community consist of 55 family households, and uniquely they live within big community of paddy-rice eater in Citizen Association 10, Sub District of Leuwi Gajah, Cimahi Selatan, Bandung, West Java, Indonesia.

Their unusual eating habit within the paddy-rice eaters has aroused the question of how the level of social interaction between the two different communities; and whether this social interaction bring the effect of food innovativeness and tendency of eating habit change for the surrounding community. The answer of this question is strongly valuable to initiate the model of extension to develop staple food diversification and to reduce the dependence upon paddyrice. Referring to Jati [7], the paddy-rice consumption for Indonesian people is the highest in the world, average of $139 \mathrm{~kg}$ of per capita per year, higher than Philippines who spent $131 \mathrm{~kg}$ of rice per year, although the Food Security Agency (FSA), Ministry of Agriculture [6] has emphasized the reducing of rice consumption in Indonesia to the $90.63 \mathrm{~kg} / \mathrm{capita} / \mathrm{year}$. This amount of rice consumption, however, is still higher than the average of world rice consumption, in which it is merely $60 \mathrm{~kg} / \mathrm{capita} /$ year [7]. Therefore, the program of rice 
consumption decreasing should be continued, and the proper model of extension is completely needed. The social interaction model could probably be enhanced to develop food diversification and change the habit of eating.

The reduction of paddy-field continuously in Indonesia has strengthened the necessity of staple food diversification. The last 1983 agricultural census (AC) indicated, the amount of Indonesian rice wetland was 16704272 ha. But, the land area was continuously decreasing to 16704272 in 1993 and 14139895 ha in 2003. The 2013 AC revealed alarming data that Indonesia had lost almost half of wet paddy field compared to $1983 \mathrm{AC}$. For more detail, the rest of wet paddy field in Indonesia was 8685888 ha based on $2013 \mathrm{AC}$, or loss of 8,013,384 ha, that means Indonesia has lose 267279 ha of paddy land per year compared to the data enquired in 1983 AC [9]. Within the shrinkage of paddy-field, the population has constantly and rapidly increases. In 1983 the Indonesian population was 158.1 million. The number has been growing to 161.6 million in $1984,165.2$ million in $1985,168,7$ million in $1986,172.2$ million in 1987, 175.6 million in 1988; and jumped to 255461686 people in 2015 . At the end of 2016 the number of Indonesian population was 258704986 people, and in 2019 the amount will become 268074565 [12].

The growing need of rice and the opposite of wet paddy land decreasing caused Indonesia faced probably the problem of food crisis. FAO, IFAD and WFP [5] pointed out the paddy land conversion is the main critical point that would disturb Indonesian food availability. The strong dependence upon rice staple food has also brought out Indonesia to get the lack of staple food availability as well as the affordability. Based on the indicator of food availability, affordability, and food quality, Indonesia has gotten the fluctuating rank within 65 to 75 , in which it has attributed Indonesia as the food unsecure state [17]. Based on the experience of Cote d'Ivoire in the phase of military conflict between Northern and Southern territory and the disruption of food supply from food surplus zone, Savane, to the food minus southern territory, revealed that the food diversification is the main way to get food self-sufficiency [14]. The food diversification of course benefits for food security, nutrition and health; secure source of income, employment and high value products; and resilience for farming system and environment service [4].

For Indonesia, the implementation of staple food diversification program is strongly possible. Center for Agricultural Data and Information System [1] exposed, Indonesia has 11 949727 ha dry land more than wetland area which is 8132345 ha in 2012. In addition, Indonesia has also unused land which is about 14252383 ha, in which it is suitable for cassava, sweet potato, and corn. However, the question is how to decrease the acute dependence on rice as a single staple food? The food innovativeness is precondition for food diversification and reducing the strong dependence upon paddy-rice. Therefore, the exploration of social interaction effect to the food innovativeness is strongly valuable to initiate the model of extension to reduce the strong dependence upon of paddy-rice staple food.

\section{Framework analysis and reasoning}

The food innovativeness for the aim of food diversification and the effort to reduce the dependence upon rice is strongly important. The research in five districts of Jakarta indicated that the food innovativeness is the proper steps to get food diversification and to change the habit of eating [16]. In this context, and based also on the research its self, the social 
interaction is the main predictor for the tendency of eating pattern change. The research in West Jakarta has found the significant effect of social interaction to the tendency of eating pattern change, while the research in North Jakarta has strengthened the previous finding, in which the effect of social interaction to the eating pattern change is not merely significant, but strongly significant [16]. This research has deeply aroused the hypothesis of social interaction to the food innovativeness.

The question of the effect of social interaction to the food innovativeness has gotten more strength by previous as well as the current research. The research of Hidalgo et al. [11], Thai [15] and Gueguen et al. [10] indicated the strong impact of social interaction to form the certain behavior. The cultural product consumption, in Hidalgo's research [11], was significantly affected by the information transmission about the observed value of the product, and it was decisively yielded by the high grade of social interaction. Quoting the 1992 prize noble winner, Gary S. Becker, Thai [15] expressed the consumption of the common goods was strongly influenced by social dimensions. In this context, the Thai's research indicated the "one group feeling" and the "close relationship feeling" are the main predictor for the tendency of similar behavior because of the equal characteristics and institutional environment. The expression of Gueguen et al. [10] has similarity of conclusion, in which the individual has a desire to make affiliation and rapport when the interact each other, and a tendency to make adaptation to the condition [2]. By the fact, hypothetically, the social interaction is strong predictor to get food innovativeness and tendency of eating behavior change.

The social interaction, referring to Sunandar [3], could be categorized into four special aspects, in which it included: the communication, partnership, understanding and family relationship. In this context, Miraningsih [18] emphasized the relationship is commonly occur between individuals and individual with the group, and also the relationship between the groups and the groups. The relationships could also be traced into the aspect of family or relatives and neighbors. The family relationship according to Sigmund Freud are basically formed by the marriage, birth and adoption that aims to create, maintain the culture, and improve physical, mental, emotional, and social from each family member [18].

The others aspect of social interaction is mutual understanding, in which it means a willingness to understand other people, especially in the aspects of feelings, thoughts, and desires. The mutual understanding, according to Sunandar [3], is the placement of self of individual in to the atmosphere of feelings, thoughts, and desires of others as close as possible. If the communicator shows sympathy for the communicant, psychologically it will support the development of a harmonious relationship atmosphere. The understanding could not possibly exist without any communications. Sunandar [3] expresses, the communication -- verbal and non-verbal -- is a channel to convey feelings, ideas, and thoughts; and at the same time it is also a medium to be able to interpret or understand the thoughts or feelings of others. Communication cannot be separated from the lives of individuals as a medium to connect others and to meet the needs. Finally, the high aspects of social interaction is a tendency to get a partnership, in which it is a joint or an effort to cooperate between individuals or groups to achieve certain goals [3].

In the light of the theories and research finding and experiences, the main predictor to the food innovativeness in this research is the social interaction, which elaborated into four sub categories: family relationship, understanding, partnership and communication.

\section{Research Methodology}


The research population is cassava eater's surrounding community in Cirendeu, West Java. The sample size based on Slovin formula by $5 \%$ of error's probability is 182 people, taken randomly from the community. The research presented two main variables, social interaction as independent variable and food innovativeness as dependent variable. The operational definition is presented in Table 1.

The two variables were measured in Likert Scale. The research instruments were completely implemented after validity and reliability test of Cronbach's alpha [8], in which it get score more than 0.6. Therefore, the instrument has met the scientific requirement. The rank of two main variables has adopted the following formula [13]:

\section{Range: The Highest Score of Likert Scale - The lowest Score of Likert Scale} The Used Likert Scale

Tabel 1. Keyword list

\begin{tabular}{|l|l|l|}
\hline Variable & Sub Variable & Operational Definition \\
\hline $\begin{array}{l}\text { Social } \\
\text { Interaction }\end{array}$ & Family relationship & $\begin{array}{l}\text { The existence of filiation with } \\
\text { cassava eater, fraternity } \\
\text { relationship by marriage, } \\
\text { children adoption, and } \\
\text { forefather kinship }\end{array}$ \\
\cline { 2 - 3 } & Understanding & $\begin{array}{l}\text { Respect to cassava eater and } \\
\text { mutual understanding }\end{array}$ \\
\cline { 2 - 3 } & Partnership & $\begin{array}{l}\text { Readiness to assist, reciprocate, } \\
\text { and work together }\end{array}$ \\
\cline { 2 - 3 } & Communication & $\begin{array}{l}\text { Frequency of meeting, } \\
\text { dialogue, sending and receiving } \\
\text { the massage. }\end{array}$ \\
\hline $\begin{array}{l}\text { Food } \\
\text { Innovativeness }\end{array}$ & $\begin{array}{l}\text { A habit and a pleasure to create a food, process, and } \\
\text { try the food's taste. }\end{array}$ \\
\hline
\end{tabular}

By this formula, the social and food innovativeness descriptively were categorized into high $(3,2-4,2)$, moderate $(2,1-3,1)$, and low (1-2). While, to browse the effect of social interaction to the food innovativeness, the research adopted the regression analysis with the following model:

$$
\begin{array}{rlcccc}
\multicolumn{9}{c}{\mathrm{Y}=\mathrm{a}+\mathrm{b} 1 \mathrm{X} 1+\mathrm{b} 2 \mathrm{X} 2+\mathrm{b} 3 \mathrm{X} 3+\mathrm{b} 4 \mathrm{X} 4+\mathrm{e}} \\
\mathrm{Y} 1= & \text { Food innovativenes } & \mathrm{X} 3 & & \text { Partnership } \\
\mathrm{A}= & \text { Constant } & \mathrm{X} 4 & = & \text { Communication } \\
\mathrm{X} 1= & \text { Family relationship } & \mathrm{e} & = & \text { Error } \\
\mathrm{X} 2 & = & \text { Understanding } & & &
\end{array}
$$

\section{Result and Discussion}

\subsection{Respondent Characteristics}

The characteristic of respondents consist of age, job, education level, and monthly income. The age and job are two important variables represented the modernity and ability to 
perform the proper decision and to solve the problem. The young age is commonly more innovative, friendly, and has the strong tendency to adopt new idea and practice which are more valuable for their life. The job also describes the wide relationship, and capacity to catch the information flow.

In this research the majority of respondents are productive age, between 20-40 years. About the job, the research found the various types of worker. However, pleasantly the research found 75 respondents $(41.20 \%)$ as the housewife and 14 persons $(7.6 \%)$ as entrepreneurs. The two kinds of job could decisively be predicted as the social capital to support the food innovativeness. The housewife will get probably to try and test many kinds of additional foods. The monthly income, in this context, should seriously be considered. The research has found the majority of respondents $(61.52 \%)$ have earned monthly less than 1 million. The lower revenue will lead someone to arrange their income to adequate the daily, weekly, and monthly needs. The food innovativeness based on the cheap raw material is a right way to decrease the strong dependence upon paddy-rice.

In the light of this finding, the respondents could strongly be predicted to get high food innovativeness. This assumption is mainly supported by the evidence of relatively high education level within the research respondents. For more clear, the majority of respondents (more than 50\%) have gotten experience of junior and senior high school - the common as well as the Islamic junior or senior high school in local context (Table 2). The good education level could probably be a main support to get a right consumption habits based on the monthly income level.4.2. Conducting Testing

In conducting the test, the author uses the keyword in Table 1 for assessment.

\subsection{Social Interaction}

The social interaction in this research is family relationship, understanding, partnership, and communication between surrounding community of cassava eater with the traditional and custom society of Cirendeu, West Java. The indicators of family relationship - in which it is measured in four stages of Likert Scale are happy feeling to attend the wedding party, comfortable feeling if one of their family members get married with traditional community, good neighborhood feeling, and happy to get a children adoption by or from traditional society, and finally the perception that the member of traditional community has gotten happy feeling if they are invited by surrounding communities to attend the wedding party. The score gotten from such indicators was categorized into high, moderate, and low (Table 3 ).

Tabel 2. The age and job of the research respondent

\begin{tabular}{|c|c|c|c|c|c|c|c|}
\hline $\begin{array}{l}\text { Charact } \\
\text { eristics }\end{array}$ & Category & Frequency & $\%$ & Characteristics & Category & $\begin{array}{l}\text { Frequ } \\
\text { ency }\end{array}$ & $\%$ \\
\hline \multirow[t]{4}{*}{ Ages } & $\begin{array}{l}20-40 \\
\text { Years }\end{array}$ & 98 & 53.84 & Education Level & ES/IES & 76 & 41.76 \\
\hline & $\begin{array}{l}40-60 \\
\text { Years }\end{array}$ & 71 & 39.02 & & JHS/IJHS & 60 & 32.97 \\
\hline & $\begin{array}{l}>60 \\
\text { Years }\end{array}$ & 13 & 7.14 & & SHS/HIS & 39 & 21.43 \\
\hline & Amount & 182 & 100 & & Diploma & 7 & 3.84 \\
\hline Job & $\begin{array}{l}\text { Private } \\
\text { Worker }\end{array}$ & 24 & 13.19 & $\begin{array}{l}\text { Monthly } \\
\text { Income }\end{array}$ & $\begin{array}{l}<\text { IDR } 1 \\
\text { million }\end{array}$ & 112 & 61.52 \\
\hline
\end{tabular}




\begin{tabular}{|l|l|l|l|l|l|l|l|}
\hline & $\begin{array}{l}\text { Casual } \\
\text { Worker }\end{array}$ & 69 & 37.89 & & $\begin{array}{l}\text { IDR 2-3 } \\
\text { million }\end{array}$ & 61 & 33.52 \\
\hline $\begin{array}{l}\text { Housewif } \\
\text { e }\end{array}$ & 75 & 41.20 & & $\begin{array}{l}\text { IDR 3-4 } \\
\text { million }\end{array}$ & 9 & 4.94 \\
\hline $\begin{array}{l}\text { Entrepren } \\
\text { eur }\end{array}$ & 14 & 7.69 & & Amount & 182 & 100.00 \\
\hline
\end{tabular}

Tabel 3. Respondent distribution based on social interaction

\begin{tabular}{|c|c|c|c|c|c|c|c|}
\hline $\begin{array}{c}\text { Sub } \\
\text { Variable }\end{array}$ & Category & Freq. & $\%$ & $\begin{array}{c}\text { Sub } \\
\text { Variable }\end{array}$ & Category & Freq. & $\%$ \\
\hline \multirow{4}{*}{$\begin{array}{c}\text { Family } \\
\text { Relationshi } \\
\text { p }\end{array}$} & High & 36 & 19.79 & \multirow[t]{4}{*}{ Partnership } & High & 61 & 33.51 \\
\hline & Moderate & 146 & 80.21 & & Moderate & 121 & 66.49 \\
\hline & Low & 0 & 0 & & Low & 0 & 0 \\
\hline & Amount & 182 & 100.00 & & Amount & 182 & 100.00 \\
\hline \multirow{4}{*}{$\begin{array}{l}\text { Understandi } \\
\text { ng }\end{array}$} & High & 33 & 18.13 & \multirow{4}{*}{$\begin{array}{l}\text { Communic } \\
\text { ation }\end{array}$} & High & 43 & 23.63 \\
\hline & Moderate & 149 & 81.87 & & Moderate & 137 & 75.28 \\
\hline & Low & 0 & 0 & & Low & 2 & 1.09 \\
\hline & Amount & 182 & 100.00 & & Amount & 182 & 100.00 \\
\hline
\end{tabular}

The mutual understanding was also measured closely by five indicators in Likert Scale, includes: (1) the feeling of respect to the indigenous society when they conduct the custom activities; (2) perception about the custom society's respect to the religious activity in the surrounding community; (3) the feeling of comfortable to get a cassava's food entertainment; (4) the feeling of happy to entertain the custom's society by cassava food; and (5) the perception about the custom society's respect to the non-cassava food.

The other five indicators were also implemented to explore and measure the partnership between the two groups of custom society and the surrounding communities. The indicators are happy feeling to: (a) help each other, (b) sale and purchase goods and services, (c) conduct mutual assistance; (d) manage the land together; and finally to (e) conduct a business cooperation. While, the five indicators to measure the tendency of warm communication are comfortable feeling to: (a) talk each other, (b) know the habit of traditional society of Cirendeu; (c) get a recommendation about the way of cassava-raw material-food processing; (d) exchange experience of food processing, and (e) send advice about the way of cassava food processing.

In the light of serial five indicators for each sub variable, the respondents got the moderate level for each sub variable of social interaction. The respondents who got the high social interaction level averagely are no more than $34 \%$ (Table 3). However, it is very important to note that partnership is one of sub variable, that the high level of it is fulfilled by $33.51 \%$ of the respondents. It clearly indicated the existence of warm partnership between the both custom society and its surrounding communities, which sequentially followed by communication, family relationship, and understanding mutually between the both different societies.

\subsection{Food Innovativeness Level}

The food innovativeness in this research is measured exclusively by eight indicators, in which it includes feeling comfortable: (a) to observe food variation made from cassava; (b) to learn the way to create food variation made from cassava; (c) to try the taste of the various 
food created from cassava; (d) to try creating the various food made from cassava raw material; (e) to process the various food made from cassavas; (f) to create the rice from cassava's raw material; (g) to make the cooked rice made from cassava; and (h) try to taste the cooked rice from cassava's raw material.

Tabel 4. Respondent distribution based on food innovativeness

\begin{tabular}{|l|c|c|c|}
\hline \multicolumn{1}{|c|}{ Variable } & Category & Freq. & $\%$ \\
\cline { 2 - 4 } \multirow{2}{*}{$\begin{array}{l}\text { Food } \\
\text { Innovativeness }\end{array}$} & High & 45 & 24.72 \\
\cline { 2 - 4 } & Moderate & 133 & 73.09 \\
\cline { 2 - 4 } & Low & 4 & 2.19 \\
\cline { 2 - 4 } & Amount & 182 & 100.00 \\
\hline
\end{tabular}

Note: Low: 1-2; Moderate: 2.1-3.1; High: 3.2-4.2

In the light of eight indicators, the research has proved that more than $73 \%$ of respondents got the moderate level of food innovativeness. The respondents who got high level of food innovativeness is no more than $28 \%$; while, the respondents who got the lower of food innovativeness level were small, merely $2.1 \%$ (Table 4). By the majority of respondents who got the moderate level of food innovativeness, it is highly potential to develop staple food diversification and decreasing the strong dependence upon rice staple food. However, of course, it needs the proper model of extension.

\subsection{The Effect of Social Interaction to the Food Innovativeness}

The social interaction with each sub variable hypothetically has a strong effect to the food innovativeness based on the above mentioned theory and research experience. The hypothesis, fortunately, proved significant and strongly significant based on the multiple regression model analysis. For more detail, the warm communication between the cassava eater communities and their surrounding society as well as the family relationship between the two different group of societies have given the strong effect for food innovativeness. The effect of two sub variables to the food innovativeness could be concluded statistically without any error probabilities. Meanwhile, the partnership within the both neighbourhood communities has merely taken the significant effect to the dependent variable of this research, indicated statistically by the $5 \%$ of error probability. The mutual understanding between the mentioned custom and common groups of society proved in contrary has not had significant effect to the food innovativeness, indicated statistically by the high error probability (Table 5).

Tabel 5. The result of multiple regression analysis

\begin{tabular}{|l|l|l|l|l|}
\hline No & $\begin{array}{l}\text { Sub Variable of Social } \\
\text { Interaction }\end{array}$ & Coe & $\mathrm{T}_{\text {count }}$ & Sig. \\
\hline & (Constant) & -0.053 & -0.155 & 0.877 \\
\hline 1 & Family Relationship & 0.377 & 4.704 & $\begin{array}{l}0.000^{*} \\
*\end{array}$ \\
\hline 2 & Understanding & 0.084 & 0.721 & 0.472 \\
\hline 3 & Partnership & 0.185 & 2.000 & $0.057^{*}$ \\
\hline 4 & Communication & 0.358 & 3.926 & $\begin{array}{l}0.000^{*} \\
*\end{array}$ \\
\hline
\end{tabular}

Note: $* *=$ Strongly Significant; $*=$ Significant 
In the light of the research finding proved by multiple regression analysis, the food innovativeness group of society could be created and replicated in several places. The agent of social change in this case could decisively adopt the field school to let the participant find and make a proper decision in food creation based on the cassava raw material. The agent of social change could kindly facilitate the food innovativeness group to extend the social interaction with the surrounding community, especially by the warm communication -- oral, gesture, as well as the social media; friendly family relationship; and followed by mutually partnership. The process will be the proper way to develop staple diversification and changing the habit of eating.

\section{Conclusion}

The research exclusively indicated the existence of food innovativeness within the surrounding community of cassava eater, and the moderate social interaction - in which it includes the communication, partnership, understanding, and family relationship - between the traditional and custom society and the surrounding society. The social interaction, especially communication, partnership, and family relationship, has excitedly given the significant and strongly significant effect to the food innovativeness. Based on the research finding, it could be created the social interaction model of extension to develop food diversification and to reduce the high dependence upon paddy-rice staple food.

Acknowledgements. This paper in conjuction with International Conference on Science and Technology, Bangunan Pejabat Timbalan Naib Canselir (Penyelidikan dan Inovasi), Universiti Putra Malaya Selangor, Malaysia.

\section{References}

[1] Center for Agriculture Data and Information System, Statistic of Agricultural Land 2008-2013, Secretariat General of Ministry of Agriculture, Jakarta, Indonesia, 2013.

[2] FAO, Corp Diversification for Sustainable Diet and Nutrition, FAO, Rome, Italy, 2012

[3] FAO, IFAD and WFP, The State of Food Insecurity in the World: Strengthening the Enabling Environment for Food Security and Nutrition. Rome: FAO, 2014

[4] S. Faul, A.S Shonghoy, and A. Dabalen, "Food Crop Diversification as a Risk Mitigation Strategy: Evidence from Cote d'Ivoire," Ide Discussion Paper No. 496, 2015

[5] Food Security Agency-Ministry of Agriculture Republic of Indonesia, Food Balance Sheet, MoA, Jakarta, Indonesia, 2012.

[6] N. Gueguen, C. Yacob, and A. Martin, "Mimicry in Social Interaction: Its Effect on Human Judgment and Behavior," European Journal of Social Sciences 8 (2), 2009, pp 253-259

[7] R. Hidalgo R., C.A., Castro, and C. Rodriguez-Sickert,C., "The Effect of Social Interaction in Primary Consumption Life Cycle of Motion Picture," New Journal of Physics 8 (52), 2006, pp 1-11.

[8] K. Jati, "Staple Food Balance Sheet, Coefficient of Variation, and Price Disparity in Indonesia," Journal of Advanced Management Science 2(1), 2014, pp 65-66;

[9] U. Maman, Y. Sugiarti, Fahriany, and F. Jie, "Determinant Factor toward Staple Food Diversification: The Evidence from Indonesia Context," The Social Science 12(9), 2017, pp. 17241730 
[10] U. Maman, N. Adiarni, and Fahriany, "Mitigation of Wetland Conversion Risk in Post-Harvest Phase to Optimize Staple Food Availability" Vol. 13(9), 2018, pp.2003-2012

[11] W. Miraningsih, Wahyu, "Hubungan Antara Interaksi Sosial dan Konsep Diri dengan Perilaku Reproduksi Sehat Pada Siswa Kelas XI di Madrasah Aliyah Negeri (MAN) Purworejo." Purworejo: UNS, 2013.

[12] National Development Planning Agency, Analysis of Household, Land, and Farming in Indonesia: Agricultural Census 2013, NDPA, Jakarta, Indonesia, 2013.

[13] R. Ritonga, "The Need of Manpower Data for Sustainable Development," The Center of Statistical Body, Jakarta, Indonesia, 2015

[14] C.J Shieh, "Effect of Cultural Shock and Cross-Cultural Adaptation on Learning Satisfaction in Mainland China Students Studying in Taiwan,” Revista Internacional de Sociologia 72 (Extra 2), 2014, pp. 57-67.

[15] R. Sitopu, R., "Farmer Participation in Organic Rice Agribusiness Application: The Case Study of Lubuk Bayas Village, District of Perbaungan, Region of Serdang Bedagai," Journal on Social Economic of Agriculture and Agribusiness 3 (4), 2014, pp. 1-11.

[16] D. Sunandar, "Pengaruh Interaksi Sosial terhadap Perilaku Konsumsi Pangan Ubi Kayu (Singkong)," Thesis, Faculty of Science and Technology, State Islamic University, Syarif Hidayatullah Jakarta, Indonesia, 2017

[17] S.H.T. Tai, "Social Interaction of Migrant and Trade Outcomes." Economic Research and Statistics Division, World Trade Organization, Rue de Lausanne, Geneva, Switzerland, 2009.

[18] Tavakol,M. and R. Dennick, "Making sense of Cronbach's alpha," International Journal of Medical Education 2, 2011, pp. 53-55. 